\title{
Sequence analysis of functional Mhc class II $\beta$ genes on quails of high- and low- IgG strains, developed by line breeding based on serum IgG concentration
}

\author{
Kazuyoshi HOSOMICHI ${ }^{1}$, Takashi SHIINA ${ }^{2}$, Sayoko, SHIMIZU ${ }^{2}$ \\ Hidetoshi INOKO ${ }^{2}$ and Kei HANZAWA ${ }^{1}$
}

\author{
1 Laboratory of animal Physiology, Faculty of agriculture, Tokyo University of Agriculture, 1737 Funako, Atsugi, Kanagawa \\ 243-0034, Japan. \\ 2 Department of Basic Medical Science and Molecular Medicine, Division of Molecular Life Science, Tokai University School of \\ Medicine, Bohseidai, Isehara, Kanagawa 259-1193, Japan
}

\begin{abstract}
In order to clarify the immunological and genetic features of functional $M h c$ class II $\beta$ genes in chicken and quails, we established a modified RT-PCR method, which classify to major or minor $B-L \beta$ genes. Using this methodlogy, we classified quail Mhc class II $\beta$ (CojaII $\beta$ ) sequences to major or minor CojaII $\beta$, and found interesting features of functional MhcII $\beta$ genes by detail comparisons between the quail and chicken, and the quail $\mathrm{H}_{\mathrm{TUA}}$ and $\mathrm{L}_{\mathrm{TUA}}$ lines. First, one major and one minor $B$ - $L \beta$ genes was identified in the chicken $\mathrm{B}^{21}$ haplotype. Four major and six minor CojaII $\beta$ genes in $\mathrm{H}_{\mathrm{TUA}}$ line and two major and seven minor Cojall $\beta$ genes in $\mathrm{L}_{\mathrm{TUA}}$ line were identified in quail two lines, respectively. Major genes were highly expressed in most of organs but minor genes were lowly expressed in a part of organs. Meanwhile, minor Cojall $\beta$ genes weakly expressed only in some immune organs, and this phenomenon suggest that these genes specifically appears depending on the modality and maturity of lymphocytes.
\end{abstract}

(Received, 18 May 2004 : Accepted, 20 July 2004)

Key words

Apis, Mhc class II gene, quail, chicken, RT-PCR

\section{血清 IgG 高低選抜ニホンウズラ系統における機能的 $M h c$ クラス II $\beta$ 遺伝子の 塩基配列解析}

\author{
細道一善 1 - 椎名 隆 2 ・清水佐良子 2 - 猪子英俊 ${ }^{2}$ ・半澤 惠 $^{1}$ \\ 1 東京農業大学農学部家畜生理学研究室、243-0034 神奈川県厚木市船子 1737 \\ 2 東海大学医学部基礎医学系分子生命科学、259-1193 神奈川県伊勢原市下糟屋 143
}

要 約

本研究では、ニワトリおよびニホンウズラの免疫器官由来細胞において発現している $M h c$ クラス II $\beta$ 遺伝子の特 徵を明らかにすることを目的に、まずニワトリ個体の主働 $B-L \beta$ あるいは微働 $B-L \beta$ に分類する方法を確立した。 次いで、この方法を用いて、ニホンウズラの $\mathrm{H}_{\mathrm{TUA}}$ 系ならびに $\mathrm{L}_{\mathrm{TUA}}$ 系に扔けるCojaII $\beta$ を主働あるいは微働 Cojall $\beta$ に分類し、ニワトリとニホンウズラの間およびニホンウズラ両系統の間における詳細な比較解析を実行す ることにより、機能的 $M h c$ クラス II $\beta$ 遺伝子の特徵を明らかにした。その結果、ニワトリでは 1 種類ずつの主働 $B-$ $L \beta$ と微働 $B-L \beta$ 、ニホンウズラ $\mathrm{H}_{\mathrm{TUA}}$ 系では 4 種類の主働 CojaII $\beta$ と 6 種類の微働 CojaII $\beta$ 、 $\mathrm{L}_{\mathrm{TUA}}$ 系では 2 種類の主 働CojaII $\beta$ と 7 種類の微働CojaII $\beta$ がそれぞれ確認された。主働遺伝子はほとんどの免疫器官由来細胞にて高い発現 量を示し、それぞれの塩基配列間の類似性が極めて低いことから免疫応答能に影響を及ぼすものと考えられた。一 方、微働遺伝子は一部の免疫器官由来細胞にて低い発現量を示し、リンパ球の種類、分化・成熟の状況によって特 異的に発現している可能性が示唆された。 
緒言

主要組織適合遺伝子複合体 $(M h c$; major histocompatibility complex）領域は、異物由来の外来抗原ペプチド を $\mathrm{T}$ 細胞に提示することにより、免疫応答の誘導に深 く関わる白血球抗原を規定する多重遺伝子族からなる ゲノム領域である。家禽では、ニワトリとウズラの $M h c$ 領域のゲノム塩基配列が決定されており、それら の配列を用いた多型解析により、Mhc 領域とマレック 病やラウス肉腫などの免疫性疾病、産卵率や卵重など の経済有用形質および免疫応答能との関連性が調べら れている。

ニワトリの $M h c$ 領域である Gado-B 領域は最小不可 欠 $M h c$ と称されて抢り、B ハプロタイプ $\mathrm{B}^{12}$ 型のゲノ ム配列 (92kb) は 1999年に Kaufman らによって報告され ており、その領域内に 2 個の機能的な $M h c$ クラス II B 遺伝子座 $(B-L \beta ; B-L \beta I$ および $B-L \beta 2) 、 2$ 個の $M h c$ ク ラス II 遺伝子座 $(B-F \alpha 1$ および $B-F \alpha 2) 、 R I N G 3$ 、 Tapasin、C型レクチン様遺伝子座 $(B-L e c)$ などを含む 19 個の遺伝子が同定されている (Guillemot ら 1988； Kaufman ら 1999)。また、B-L $\beta$ のうち、RING3 と Tapasin 遺伝子座との間に位置する $B-L \beta 2$ は発現量が 多く、かつ主要に機能する主働 (Major) 遺伝子座であ るのに対し、Tapasin とB-Lec 遺伝子座との間に位置 する $B-L \beta 1$ は発現量が少なく、かつ組織特異的発現 を示す微㗢 (Minor) 遺伝子座であると報告されている (図 1、Kaufman ら 1999; Jacob ら 2000)。

一方、ニホンウズラの $M h c$ 領域は Coja 領域と称さ
れており、Coja ハプロタイプ1 型のゲノム配列 $(180 \mathrm{~kb})$ は2004 年に Shiinaらによって報告された (Shiinaら 2004）。この領域には 7 個の機能的な $M h c$ クラス II $\beta$ 遺伝子座 (CojaII $\beta$; Coja-DAB1, -DBB1, -DCB1, -DDB1, $-D E B 1,-D F B 1$ および-DGBI)、 5 個の $M h c$ クラス I 遺 伝子座 (Coja-B1, -B2, -D1, -D2, -E)、RING3、Tapasin、 C 型レクチン様遺伝子座 (Coja-Lec) などを含む 41 個の 遺伝子が同定されている (Shiina ら 1999, 2004)。これ らのうちCojaII $\beta$ においては、発現解析ならびに RING3、Tapasin 抄よびCoja-Lec 遺伝子座との位置関 係より、Coja-DAB1 および-DBB1 が主働 Mhc クラス II $\beta$ 遺伝子座 (主働 CojaII $\beta$ ) であり、Coja-DCB1、 -DDB1、-DEB1、-DFB1 および-DGB1 が微働 $M h c$ クラ ス II $\beta$ 遺伝子座 (微働 CojaII $\beta$ ) であることが示唆され ている(図 1、Shiina ら 2004)。これらのことから、 CojaII $\beta$ は $B-L \beta$ に比べて多様なゲノム構造をしてお り、抗原提示機能を介して引き起こされる免疫応答能 ならびに抗病性において、ニホンウズラはニワトリよ りも著しい多様性を有しているものと考えられる。し たがって、B-L $\beta$ とCojaII $\beta$ の遺伝学的特徴を明らかに することは免疫応答におけるニワトリとニホンウズラ 間の相違を理解するために極めて重要である。また、 獲得免疫で主体をなす $\mathrm{T}$ 細胞や $\mathrm{B}$ 細胞は一次免疫器官 である胸腺およびファブリシウス囊でそれぞれ分化・ 成熟するが、成熟過程において特有の表面抗原を発現 することから、微働 $B-L \beta$ 抗原は未成熟リンパ球に特 有なものであるとの見解もある (Jacobら 2000)。さら

\section{$B-L \beta$ Region (55.5kbp)}

Fig. 1. Location of major and minor CojaII $\beta$ loci in Coja haplotype 1. Lines show orthologous loci between quail and chicken. 
にMhcII $\beta$ 抗原は主にヘルパー T 細胞に対する外来性 抗原の提示という機能を担っていることから、ニホン ウズラの血清 $\mathrm{IgG}$ 值による高低両選抜系統である High IgG系 ( $\mathrm{H}_{\mathrm{TUA}}$ 系) と Low IgG系 ( $\mathrm{L}_{\mathrm{TUA}}$ 系) (Watanabe と Nagayama1979) の間には機能的な Cojall $\beta$ の発現量や組織特異性などに差異が認められる可能 性が考えられる。

本研究では、ニワトリおよびニホンウズラの免疫 臟器における機能的 $M h c I I \beta$ 遺伝子の特徴を明らかに するために、まずハプロタイプ $\mathrm{B}^{21}$ 型のニワトリを対 象とし、免疫臓器および末梢リンパ球において発現 している $B-L \beta$ の塩基配列を決定し、塩基配列型の出 現頻度から主働 $B-L \beta$ と微働 $B-L \beta$ に分類した。その 後、同様の手法によってニホンウズラの $\mathrm{H}_{\mathrm{TUA}}$ 系拉よ び $\mathrm{L}_{\mathrm{TUA}}$ 系における主働 CojaII $\beta$ と微働 CojaII $\beta$ を推定 した。

\section{材料および方法}

1 全 RNA の抽出

供試鵎には (財) 日本生物科学研究所において閉鎖集 団として飼育管理されているハプロタイプ $\mathrm{B}^{21}$ 型のニ ワトリGSP系から 5 週齢の雄 1 個体を用いた。また、 供試ウズラには東京農業大学農学部家畜生理学研究室 において閉鎖集団として飼育管理されている $\mathrm{H}_{\mathrm{TUA}}$ 系 および $\mathrm{L}_{\mathrm{TUA}}$ 系から 3 週齢の雄 1 個体ずつを用いた。 全 RNA 抽出は胸腺、ファブリキウス襄、脾臟および 末梢リンパ球を材料とし、TRIZOL REAGENT (インビ トロジェン)を用いて行った。

\section{RT-PCR}

RT-PCR は、まず免疫臟器および末梢リンパ球由来 の全RNA 鋳型として First Strand cDNA Synthesis Kit ReverTra Ace- $a$ - (東洋紡) を用いて cDNA を合成した。

プライマーは、ニワトリでは、GenBankに登録され ているすべての $B-L \beta$ の共通配列から、 $\beta 1$ ドメイン 領域 (エクソン 2) 〜 細胞膜貫通領域 (エクソン 4) 間の 604 bp を特異的に増幅させる共通プライマーEx2a (5'gagtgccactacctgaacggcaccgagcgg-3') およびEx4 (5'gcgccaggaagacgagccccagcac-3’) を設計した (Zoorob ら 1993）。また、ニホンウズラは、これまで著者らが解 析したすべてのCojaII $\beta$ のシグナルペプチド領域 (エク ソン 1)〜 $\beta 2$ ドメイン (エクソン 3) 領域間の $411 \mathrm{bp}$ $441 \mathrm{bp}$ を特異的に増幅させる共通プライマー $\mathrm{C} 2 \mathrm{BNO} 2$ (5'-ccggtctgctacggaac-3') および C2BNO5 (5'aaccacttcaccttcacctccatctc-3'）を設計した。
その後、PCR 増幅は、サーマルサイクラーGene Amp PCR System 9700 (Applied Biosystems) を使用し、 プレ熱変性： $96{ }^{\circ} \mathrm{C} 、 3$ 分間の後、熱変性： $96{ }^{\circ} \mathrm{C} 、 30$ 秒 間、アニーリング： $63{ }^{\circ} \mathrm{C} 、 30$ 秒間、伸長反応： $72{ }^{\circ} \mathrm{C}$ 、 30 秒間のサイクルを 30 回繰り返し、さらに $72{ }^{\circ} \mathrm{C} 、 5$ 分間にて最終伸長反応を行った。

\section{3 塩基配列解析}

RT-PCR 産物のクローニングは、pGEM-T easy Vector System (プロメガ) およびDH5a Competent high (東洋紡)を用い、PCR 産物ごとに、ニワトリで 24 ク ローン、ウズラで 48 クローンずつ調製した。塩基配 列はBig Dye Terminator Cycle Sequencing Ready Reaction Kit v1.1(アプライドバイオシステムズ) およ びABI PRISM 377 (アプライドバイオシステムズ)を用 いて決定した。塩基配列デー夕は遺伝情報処理ソフト ウェア GENETYX Mac v11.0(ソフトウェアデベロプメ ント) および類似配列検索プログラム BLASTを用いて 解析した。

\section{4 分子系統的解析}

$B-L \beta$ およびCojaII $\beta$ 遺伝子間の類縁関係を解析す るために、本研究で新たに決定した 16 個の発現遺伝 子 (DDBJ/EMBL/ GenBank accession No.AB181861 $\mathrm{AB} 181874 、 \mathrm{AB} 181876$ および $\mathrm{AB} 181877$ ）の塩基配列 ならびに 15 種類の既知配列を CLUSTALW プログラ ム $(\mathrm{DDBJ})$ を用いて、整列化させた後、近隣結合法 (Saitou と Nei 1985)によって系統樹を作成した。なお、 系統樹作成の外群にはヒト $M H C$ クラス II 抗原遺伝子 HLA-DRB1*0101（AF142457）を用いた。また、系統樹 作成の際に用いたその他の既知配列は以下の通りで ある。すなわち、ニワトリハプロタイプ $\mathrm{B}^{2}$ 型、 $\mathrm{B}^{4}$ 型、 $\mathrm{B}^{12}$ 型、 $\mathrm{B}^{14}$ 型、 $\mathrm{B}^{15}$ 型、 $\mathrm{B}^{19}$ 型および $\mathrm{B}^{21}$ 型の $B-L \beta$ mRNA (AJ248576、AJ248583、AJ248572、AJ248581、 AJ248585、AJ248577、AJ248584、AJ248579、 AJ248580、AJ248582、AJ248574、AJ248586、 AJ248575 およびAJ248573)である。

\section{結 果}

$1 \quad B^{2} 1$ 型ニワトリにおける発現 $B-L \beta$ 遺伝子の塩基 配列解析

ニワトリハプロタイプ $\mathrm{B}^{21}$ 型の、胸腺、ファブリ キウス襄、脾臟および末梢リンパ球に由来する RTPCR 産物のクローンのうち、それぞれ13、16、14 お よび 13 クローン、計 56 クローンの塩基配列を決定 
した (表 1)。決定した塩基配列のエクソン 2 に相当す る部分 (244bp) は $B^{21}-B-L \beta 2(\mathrm{AJ} 248585)$ あるいはは $B^{21}-B-L \beta 1$ (AJ248586) と完全に一致した。しかしなが ら、その他の B ハプロタイプの塩基配列との類似性は 99.2\%以下を示した。したがって、得られた RT-PCR 産物はハプロタイプ $\mathrm{B}^{21}$ 型の塩基配列であり、ハプロ タイプ B ${ }^{21}$ 型は既報（Kaufman ら 1999; Jacobら 2000） どおりに2 個の機能的な遺伝子座を有することが確認 された。また、これらの塩基配列は出現頻度が異なり、 主働遺伝子座である $B-L \beta 2$ は全ての臓器において $78.6 \%$ 以上の高い出現頻度を示し、特に胸腺と末梢リ ンパ球においては $100 \%$ の出現頻度であった。一方、 微動遺伝子座である $B-L \beta 1$ はファブリキウス霟およ び脾蔵においてのみ認められ、その出現頻度は 12.5 お よび $21.4 \%$ と低い值を示した。なお、胸腺および末梢 血リンパ球においては $B-L \beta 1$ の発現は認められなか った(表1)。

\section{2 二ホンウズラ $H_{T U A}$ 系における発現 Cojall $\beta$ 遺伝 子の塩基配列解析 \\ ニホンウズラ $\mathrm{H}_{\mathrm{TUA}}$ 系の胸腺、ファブリキウス震、} 脾臟掞よび末梢リンパ球に由来する RT-PCR 産物のク ローンのうち、それぞれ30、24、16および29クロー ン、計 99 クローンの塩基配列を決定したところ、10 タイプの塩基配列型が見い出された (表2)。これら 10 タイプの塩基配列型について、Coja ハプロタイプ1型 の CojaII $\beta$ のゲノム配列との相同性を解析したところ、 これらのうち 5 タイプは、Coja-DAB1、-DBB1、 -DCB1、-DFB1 あるいはDGBI (AB078884) のいずれか と完全に一致し、1タイプはCoja-DEB1 と $99.6 \%$ 極 めて高い類似性を示した。したがって、これら 6 夕イ プは上記遺伝子座に由来する対立遺伝子であると判断 L、Coja-DAB1*01、-DBBI*01、-DCB1*01、 $-D E B 1 * 02 、-D F B 1 * 01$ および-DGBI*01（AB181861〜
AB181863、AB181865 およびAB181866）と命名した。 一方、残りの 4 タイプの塩基配列型は、ハプロタイプ 1 型の CojaII $\beta$ のゲノム配列との間、ならびに 4 タイ プの塩基配列型相互間に扮ける類似性が $77.4 \%$ $87.8 \%$ と低いことから、未同定の遺伝子座に由来する ものと判断し、CojaII $\beta-01 、-02 、-04$ および-12 （AB181870～AB181873）と命名した (表 2)。

各免疫臓器および末梢リンパ球における 10 タイプ の塩基配列型の組織特異性や出現頻度について比較す ると、Coja-DAB1*01、-DBB1*01 およびCojaII $\beta-02$ は 全ての組織において発現が確認され、その出現頻度は 末梢リンパ球におけるCoja-DABI*01の $3.4 \%$ を除き、 いずれも $10 \%$ 以上の高い值を示した。他方、CojaII $\beta$ 01 は胸腺、脾臟および末梢リンパ球において $20 \%$ 以 上の極めて高い出現頻度を示し、特に末梢リンパ球で は $58.6 \%$ と最も高い出現頻度を示した。しかしながら、 ファブリシウス襄では発現が認められなかった。また、 CojaII $\beta$-04 は胸腺、ファブリキゥス襄および脾臓にお いてはその発現が確認されたが、末梢リンパ球では認 められなかった。一方、Coja-DCB1*01、-DFB1*01、 および-DGB1*01 は 1 つの組織での発現しか認められ ず、その出現頻度は $20 \%$ 未満の低い值を示した。

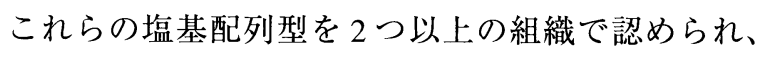
その割合が $20 \%$ 以上であったものを主働遺伝子、割 合がいずれも $20 \%$ 未満であったものを微働遺伝子と 分類したところ、Coja-DAB1、-DBB1、Cojall $\beta-01$ お よび-02の 4 種類の塩基配列型は出現頻度から主働 CojaII $\beta 、$ Coja- DCBI*01、-DEBI*02、-DFBI*01、 -DGBI*01、Cojall $\beta-04$ および-12の 6 種類の塩基配列 型は微働CojaII $\beta$ であると推測した。

\section{3 二ホンウズラ L TUA 系における発現 Cojall $\beta$ 遺伝 子の塩基配列解析 \\ ニホンウズラ $\mathrm{L}_{\mathrm{TUA}}$ 系の 4 組織に由来する RT-PCR}

Table 1. Expression patterns and its frequencies of functional $B-L \beta$ genes derived from immuno organs of $B^{21}$ homozygous chicken

\begin{tabular}{ccccccr}
\hline \multirow{2}{*}{ Locus } & Clone names & $\begin{array}{c}\text { Nucleotide homologies } \\
\text { with locus (\%) }\end{array}$ & Thy & Bru & Spl & Ply \\
\cline { 2 - 7 } & & $\mathrm{n}$ & 13 & 16 & 14 & 13 \\
\hline$B-L \beta 2$ & $G S P-B-L \beta 2$ & 100.0 & 100.0 & 87.5 & 78.6 & 100.0 \\
$B-L \beta 1$ & $G S P-B-L \beta 1$ & 100.0 & 0.0 & 12.5 & 21.4 & 0.0 \\
\hline
\end{tabular}

Thy: thymus, Bur: bursa of fabricius, Spl: spleen, and Ply: peripheral lymphocytes 
Table 2. Expression patterns and its frequencies of functional CojaII $\beta$ genes derived from immuno organs of Japanese quail $\mathrm{H}_{\text {TUA }}$ and $\mathrm{L}_{\text {TUA }}$ lines

\begin{tabular}{|c|c|c|c|c|c|c|c|c|c|c|c|}
\hline \multirow{3}{*}{ Locus } & \multirow{3}{*}{$\begin{array}{l}\text { Allele or clone } \\
\text { name }\end{array}$} & \multirow{3}{*}{\multicolumn{2}{|c|}{$\begin{array}{c}\text { Nucleotide } \\
\text { homologies with } \\
\text { Coja gene }(\%)\end{array}$}} & \multicolumn{4}{|c|}{$\mathrm{H}_{\mathrm{TUA}}$ line } & \multicolumn{4}{|c|}{$\mathrm{L}_{\mathrm{TUA}}$ line } \\
\hline & & & & \multicolumn{4}{|c|}{ Organs } & \multicolumn{4}{|c|}{ Organs } \\
\hline & & & & Thy & Bur & Spl & Ply & Thy & Bur & Spl & Ply \\
\hline Contig 1 & & & $\mathrm{n}$ & 28 & 24 & 16 & 29 & 22 & 38 & 22 & 25 \\
\hline Coja-DABI & Coja-DAB1*01 & 100.0 & & 25.0 & 12.5 & 25.0 & 3.4 & 0.0 & 0.0 & 0.0 & 0.0 \\
\hline Coja-DBB1 & Coja-DBB1*01 & 100.0 & & 17.9 & 29.2 & 12.5 & 20.7 & 0.0 & 0.0 & 0.0 & 0.0 \\
\hline \multirow[t]{2}{*}{ Coja-DCBI } & Coja-DCB1 $* 01$ & 100.0 & & 0.0 & 4.2 & 0.0 & 0.0 & 0.0 & 0.0 & 0.0 & 0.0 \\
\hline & Coja-DCB1*02 & 99.6 & & 0.0 & 0.0 & 0.0 & 0.0 & 0.0 & 2.6 & 0.0 & 0.0 \\
\hline Coja-DDBl & Coja-DDB1*01 & - & & 0.0 & 0.0 & 0.0 & 0.0 & 0.0 & 0.0 & 0.0 & 0.0 \\
\hline \multirow[t]{2}{*}{ Coja-DEB1 } & Coja-DEB $1 * 01$ & - & & 0.0 & 0.0 & 0.0 & 0.0 & 0.0 & 0.0 & 0.0 & 0.0 \\
\hline & Coja-DEB $1 * 02$ & 99.6 & & 0.0 & 8.3 & 0.0 & 0.0 & 0.0 & 0.0 & 0.0 & 0.0 \\
\hline \multirow[t]{2}{*}{ Coja-DFB1 } & Coja-DFB1*01 & 100.0 & & 3.6 & 0.0 & 0.0 & 0.0 & 4.5 & 0.0 & 9.1 & 0.0 \\
\hline & Coja-DFB1*02 & 99.3 & & 0.0 & 0.0 & 0.0 & 0.0 & 0.0 & 2.6 & 0.0 & 4.0 \\
\hline \multirow[t]{2}{*}{ Coja-DGBI } & Coja-DGB1*01 & 100.0 & & 0.0 & 0.0 & 0.0 & 3.4 & 0.0 & 0.0 & 0.0 & 0.0 \\
\hline & Coja-DGB1*02 & 98.9 & & 0.0 & 0.0 & 0.0 & 0.0 & 13.6 & 0.0 & 0.0 & 0.0 \\
\hline \multicolumn{12}{|c|}{ Tentatively named genes } \\
\hline & Cojall $\beta-01$ & & & 21.4 & 0.0 & 25.0 & 58.6 & 0.0 & 0.0 & 0.0 & 0.0 \\
\hline & CojaII $\beta-02$ & & & 17.9 & 29.2 & 25.0 & 13.8 & 0.0 & 0.0 & 0.0 & 0.0 \\
\hline & CojaII $\beta-04$ & & & 14.3 & 4.2 & 6.3 & 0.0 & 0.0 & 0.0 & 0.0 & 0.0 \\
\hline & Cojall $\beta-12$ & & & 0.0 & 12.5 & 6.3 & 0.0 & 0.0 & 0.0 & 0.0 & 0.0 \\
\hline & Cojall $\beta-13$ & & & 0.0 & 0.0 & 0.0 & 0.0 & 22.7 & 47.4 & 50.0 & 60.0 \\
\hline & Cojall $\beta-14$ & & & 0.0 & 0.0 & 0.0 & 0.0 & 54.5 & 44.7 & 36.4 & 36.0 \\
\hline & Cojall $\beta-15$ & & & 0.0 & 0.0 & 0.0 & 0.0 & 4.5 & 2.6 & 4.5 & 0.0 \\
\hline
\end{tabular}

Thy: thymus, Bur: bursa of fabricius, Spl: spleen, and Ply: peripheral lymphocytes

Bold numbers indicate expression frequencies over $20 \%$.

産物のクローンには 7 タイプの塩基配列型が見い出さ れた (表 2)。これらの塩基配列型について、Coja八 プロタイプ 1 型の CojaII $\beta$ のゲノム配列と比較したと ころ、これら 7 種類のうち 1 タイプは Coja-DFB1 と 完全に一致し、また 3 タイプはCoja-DCB1、-DFB1 あるいは-DGBI と $98.9 \%$ 以上の高い類似性を示し た。したがって、これら4タイプは上記遺伝子座に 由来する対立遺伝子であると判断し、Coja$D C B 1 * 02 、-D F B 1 * 01 、-D F B 1 * 02$ および-DGB1*02 (AB181864、AB181866、AB181867 およびAB181869) と命名した。一方、残りの 3 タイプの塩基配列型は、 ハプロタイプ 1 型の CojaII $\beta$ のゲノム配列との間、お よび $\mathrm{H}_{\mathrm{TUA}}$ 系で新規に同定されたCojaII $\beta-01 、-02 、-04$ および-12 との間で 75.6〜 89.3\%と低い類似性を示し
た。そこで、これら 3 種類の塩基配列型は、未同定の 遺伝子座に由来するものと判断し、CojaII $\beta-13 、-14$ お よび-15（AB181874、AB181876および AB181877）と 命名した。

4 組織におけるこれら 7 タイプの塩基配列型の組織 特異性や出現頻度について比較すると、CojaII $\beta-13$ お よび-14は全ての組織において発現が確認され、その 出現頻度は $20 \%$ 以上の高い值を示した。一方、

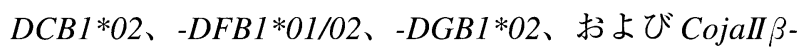
15 は組織特異性を示し、 $D G B 1 * 02$ の胸腺における $13.6 \%$ 除き、いずれも $9.1 \%$ 以下の低い出現頻度を 示した（表2）。

CojaII $\beta-13$ および-14の 2 種類の塩基配列型は出現 頻度から主働 CojaII $\beta$ 、Coja-DCB1*02、-DFB1*01、 
$-D F B 1 * 02 、-D G B 1 * 02$ および CojaII $\beta-15$ の 5 種類の塩 基配列を微働CojaII $\beta$ であると推測した。

\section{$4 H_{T \cup A}$ 系と L TUA 系における発現 Cojall $\beta$ 遺伝子 の比較}

$\mathrm{H}_{\mathrm{TUA}}$ 系、 $\mathrm{L}_{\mathrm{TUA}}$ 系の両系個体にて得られた塩基配列 の組織特異性、出現頻度および類似性を比較した。八 プロタイプ 1 に含まれる Coja-DDB1*01 と-DEB1*01 は 両系統で発現が認められなかった。次いで、両系間で 完全に一致した配列はCoja-DFBI*01 のみであったが、 Coja-DCB1*01 と-DCB1*02、Coja-DFB1*01 と-DFB1*02 抢よびCoja-DGBI*01 と-DGBI*02 はそれぞれ 99.6\%、99.3\%および $98.9 \%$ とお互いに高い類似性 を示した。これら 7 種類の塩基配列型は出現頻度から 微働CojaII ßであると推測された (表 2)。また、各 Coja 遺伝子座と組織特異性との関係を調べた結果、 Coja-DCB1 は、 $\mathrm{H}_{\mathrm{TUA}}$ 系、 $\mathrm{L}_{\mathrm{TUA}}$ 系ともにファブリキウ ス囊にのみ検出された。これに対して、両系個体間で 発現している臓器が異なる遺伝子も認められた。すな わちCoja-DFB1 は、 $\mathrm{H}_{\mathrm{TUA}}$ 系では胸腺のみで検出され たが、 $\mathrm{L}_{\mathrm{TUA}}$ 系ではすべての組織にて検出され、また Coja-DGB1 は、 $\mathrm{H}_{\mathrm{TUA}}$ 系では胸腺のみで検出されたが、 L TUA 系では末梢リンパ球のみに検出された。

一方、高い出現頻度を有する主働 CojaII $\beta$ は、 $\mathrm{H}_{\mathrm{TUA}}$ 系においてCoja-DAB1*01、-DBB1*01、CojaII $\beta-01$ 、 $-02 の 4$ 種類、また $\mathrm{L}_{\mathrm{TUA}}$ 系において Cojall $\beta-13$ と-14 の 2 種類であった (表 2)。この主働 CojaII $\beta$ 間の類似 性は $80.0 \%$ \% $1.9 \%$ と低い值を示し、両系個体間に おける主働CojaII $\beta$ は極めて異なる構造を有している と推測された。

\section{5 発現 Cojall $\beta$ 遺伝子の分子系統的解析}

DNA データベースに登録されているB-L $\beta$ 、Coja 八 プロタイプ1のCojaII $\beta$ ならびに本研究にて得られた ニホンウズラCojaII $\beta$ の間㧍よび主働遺伝子と微働遺 伝子の間の類縁関係を明らかにするためにニワトリ 14 種類、ニホンウズラ 16 種類掞よびヒト 1 種類の合計 32 種類の塩基配列を用いて系統樹解析をおこなった (図 2)。その結果、CojaII $\beta$ は $B-L \beta$ と異なる集団を形 成し、CojaII $\beta$ 集団の中でさらに 3 つの亜集団 (図 2 の $\mathrm{A}, \mathrm{B}, \mathrm{C})$ に大別された。これらのうち、主働 CojaII $\beta$ と考えられる 6 種類の塩基配列のうち、亜集団 $\mathrm{C}$ に属 するCojaII $\beta$-01 を除いた 5 種類は亜集団 B に属した。 ところが、亜集団 B には、微働遺伝子であるCoja$D F B 1 * 01 、-D F B 1 * 02 、$ CojaII $\beta-15$ が含まれることから、
これら 3 つの亜集団を主働遺伝子集団と微働遺伝子集 団に明磪に分類することは不可能であった(図2)。

\section{考察}

ニワトリにおいて、主働遺伝子座である $B-L \beta 2$ の mRNA はすべての臓器から高い頻度で確認されたが、 微働遺伝子座である $B-L \beta I$ の mRA は一部の臓器で のみ低い頻度で確認された (表 1)。この結果は既知の 報告と完全に一致した（Kaufman ら 1999; Jacob ら 2000）。このことより、RT-PCR 産物由来の塩基配列の 出現頻度が、mRNAの発現の多寊を反映しており、本 実験方法が遺伝子の発現の割合を調查するのに有効で あることが証明された。

ニホンウズラでは、ニワトリと比べ多種類の配列が 確認されたが、ニワトリ同様に出現頻度に偏りが確認 された(表2)。このことからニホンウズラはニワトリ に比べ多くの遺伝子重複が認められるが、ニワトリ同 様に主働遺伝子座と微働遺伝子座が存在することが明 確となった。特にニホンウズラのCoja ハプロタイプ 1 とニワトリの $M h c$ 領域のゲノム塩基配列から主働遺伝 子座の位置を比較すると、ニワトリの主働遺伝子座で ある B-L 32 が位置する Tapasin と RING3 遺伝子座との 間のゲノム領域に、ニホンゥズラでは Coja-DAB1 およ び-DBB1 が同定された（図 1、Kaufman ら 1999; Shiina ら 2004)。本実験において $\mathrm{H}_{\mathrm{TUA}}$ 個体の Coja-DABI お よび-DBB1 由来の RT-PCR 産物の出現頻度がニワトリ $B-L \beta 2$ と同様に高かったことから、Cojaハプロタイプ 1 を持つニホンウズラにおいてはCoja-DAB1 および -DBBI が主働遺伝子座であることが示唆された。した がって、本研究によって新たに同定された、出現頻度 の高い 4 種類の塩基配列 (CojaII $\beta-01 、$ CojaII $\beta-02$ 、 CojaII $3-13 、 C o j a I I \beta-14)$ は主働遺伝子座であり、かつ Tapasin と RING3 との間のゲノム領域に存在する可能 性が高いと考えられた（細道ら、未発表）。ところが、 これら 4 種類の塩基配列は、Coja-DAB1 および-DBB1 の塩基配列と類似性が低いことから、いわゆる一般的 な同一遺伝子の対立遺伝子間の関係とは異なるものと も考えられた(図 2)。この点に関する議論として、ヒ トの $M h c$ クラス II 遺伝子の DR ファミリーの例が挙げ られる。このファミリーは1つの $\alpha$ 鎖 $(D R A)$ および複 数個の $\beta$ 鎖 $(D R B)$ より構成されるが、DRBの対立遺 伝子の類似性および遺伝子座数はハプロタイプにより 異なることが知られている (Corell ら 1992)。したがっ

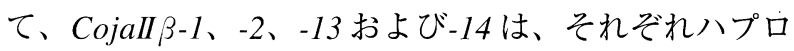
タイプ1（Coja-DABI*01 および-DBBI*01）とは異なる 


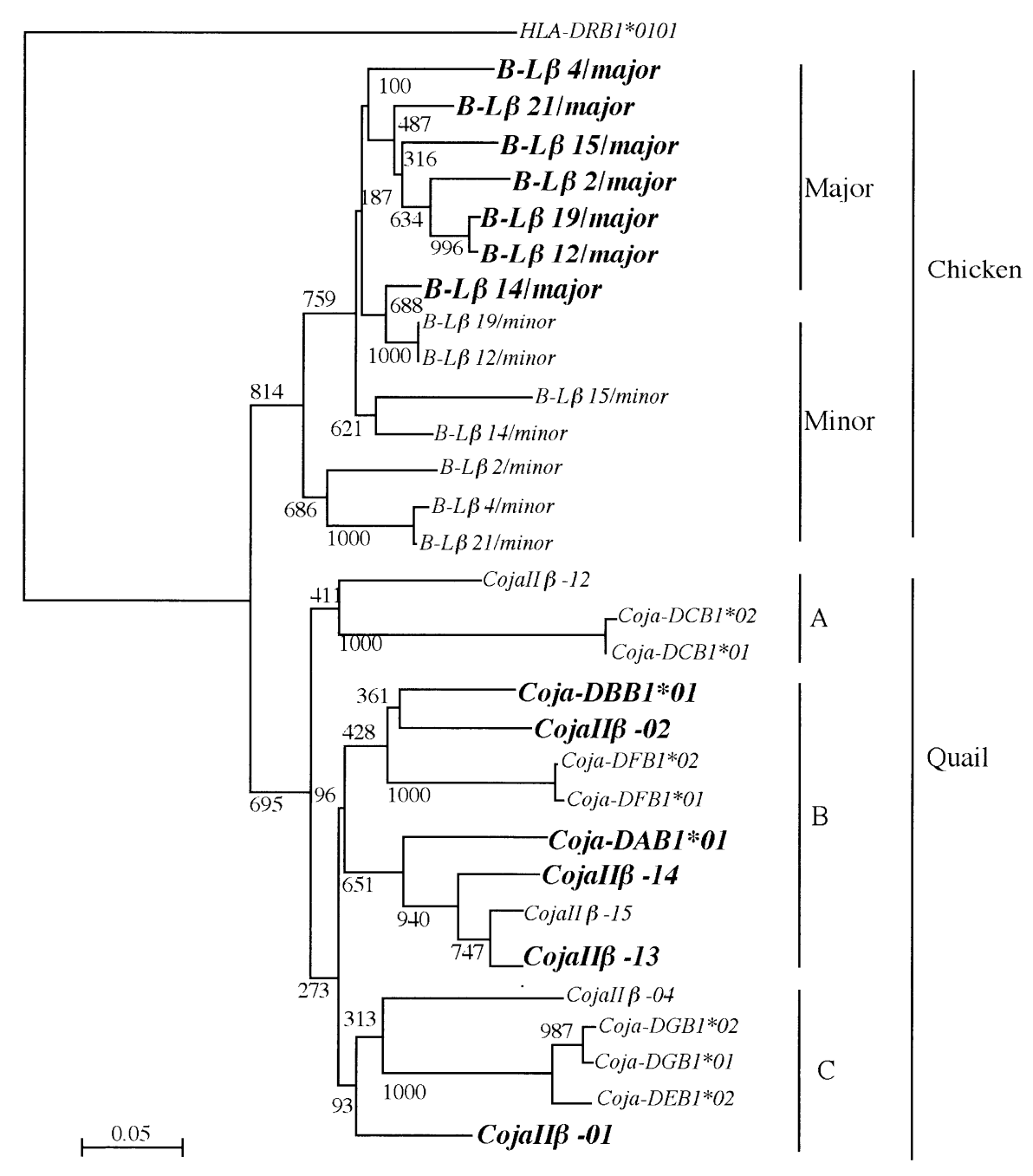

Fig. 2. Phylogenetic trees showing the genetical relationships of the Mhc class II $\beta$. The dendrograms was constructed from the nucleotide sequences of the $\beta 1$ extracellular domain region (from exon 2) (270 nucleotides in length) of $M h c$ class II $\beta$ genes. Values near the branchpoints of the tree indicate bootstrap values. The number in parenthesis indicates GenBank accession number. (A), (B) and (C) indicate sub-groups in quail lineage. Bold letters show major $M h c I B$.

Coja ハプロタイプ由来の遺伝子座であると考えられ た。さらに、これら主㗢遺伝子のそれぞれの類似性の 差異からクラス II 抗原の提示能や $\mathrm{T}$ 細胞レセプターと の親和性にも差異を有する可能性が考えられ、Coja八 プロタイプと免疫性疾病および免疫応答能ひいては各 種経済形質との関連が予想された。すなわち、これら の主働遺伝子を含むCoja ハプロタイプの違いこそが、 ニホンウズラの血清 $\mathrm{IgG}$ 濃度の高低に関与する可能性 が示唆された (清水ら 2004)。
一方、微働遺伝子座由来と考えられる塩基配列は、 主働遺伝子座由来と考えられる塩基配列が互いに類似 性が低かったのとは対照的に、高い類似性を示す 3 組：Coja-DCB1*01/-DCB1*02、-DFB1*01/-DFB1*02 お よび-DGB1*01/-DGB1*02 の塩基配列が確認された

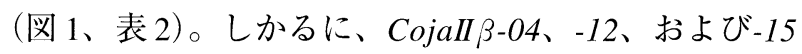
は他のいずれの塩基配列とも類似性が低かった。した がって、これらの塩基配列も主働遺伝子座と共に連鎖 するCoja ハプロタイプ特異的な遺伝子座であると考 
えられた。さらに、これら微働遺伝子座は一部の臓器 に低い頻度で確認されており、その臟器も様々である ことから、微㗢遺伝子座には、リンパ球の種類、ある いは分化・成熟の状況によって特異的に発現する遺伝 子座も存在する可能性が考えられた。また、これら微 働遺伝子の差異は主働遺伝子と共にクラス II 抗原の提 示能や $\mathrm{T}$ 細胞レセプターとの親和性にも差異を有する 可能性が考えられた。

図 2 の系統樹より、CojaII $\beta$ はニワトリとの種分化 後に遺伝子重複により形成されたことが示唆され た。また、主働CojaII $\beta$ の集団には微働CojaII $\beta$ が 含まれることから、CojaII $\beta$ は遺伝子座ごとに異な る選択圧あるいは極度の Birth and death evolutionに より形成されたと考えられた（Ota ら 1994；Nei ら 1997）。そのような遺伝的な変化がウズラとニワト リとの MhcII $\beta$ の発現量の差異に影響を及ぼした可能 性がある(図 3)。著者らは両者間におけるこのような 遺伝的な変化はニワトリが留鳥なのに対して、ニホン ウズラは渡り鳥であるために、ニホンウズラはニワト リよりもより多くの抗原に暴露され、それに対する適 応策として、ウズラの抗原認識機構を発達させたと推 測している。

\section{謝 辞}

本研究の一部は日本学術振興事業団科学研究費基盤 研究 B (課題番号：13460135) ならびに平成 14、15 年 度私立大学教育研究推進特別補助 (B3) の支援を受け て実施した。また、本研究の実施に当たり、供試䳕を ご提供頂くなど種々の便宜を扔計り頂いた（財）日本生 物科学研究所の水谷誠博士に、この場を借りて深謝致 します。

\section{引用文献}

Corell A, Morales P, Varela P, Paz-Artal E, Martin-Villa JM, Martinez-Laso J. Arnaiz-Villena A. 1992. Allelic diversity at the primate major histocompatibility complex DRB6 locus. Immunogenetics, 36: 33-38.

Guillemot F, Billault A, Pourquie O, Behar G, Chausse A, Zoorob R, Kreibich G, Auffray C. 1988. A molecular map of the chicken major histocompatibility complex: the class II $\beta$ genes are closely linked to the class I genes and the nucleolar organizer. EMBO J., 7: 2775-2785.

Jacob JP, Milne S, Beck S, Kaufman J. 2000. The major and a minor class II beta-chain (B-LB) gene flank the
Tapasin gene in the B-F/B-L region of the chicken major histocompatibility complex. Immunogenetics, 51: $138-147$.

Kaufman J, Milne S, Gobel TW, Walker BA, Jacob JP, Auffray C, Zoorob R, Beck S. 1999. The chicken B locus is a minimal essential major histocompatibility complex. Nature, 401: 923-925.

Nei M, Gu X, Sitnikova T. 1997. Evolution by the birthand-death process in multigene families of the vertebrate immune system. Proc. Natl. Acid. Sci. USA, 94: 7799-7806

Ota T, Nei M. 1994. Divergent evolution and evolution by the birth-and-death process in the immunoglobulin $\mathrm{VH}$ gene family. Mol. Biol. Evol., 11: 469-482.

Saitou N, Nei M. 1987. The neighbor-joining method: a new method for reconstructing phylogenetic trees. Mol. Biol. Evol., 4: 406-525.

Shimizu S, Shiina T, Hosomichi K, Takahashi S, Koyama T, Onodera T, Kulski JK, Inoko H. 2004. MHC class IIB gene sequences and expression in quails (Coturnix japonica) selected for high and low antibody responses. Immunogenetics, 56 (4): 280-291.

Shiina T, Shimizu C, Oka A, Teraoka Y, Imanishi T, Gojobori T, Hanzawa K, Watanabe S. and Inoko H. 1999. Gene organization of the quail major histocompatibility complex (MhcCoja) class I gene region. Immunogenetics, 49: 384-394.

Shiina T, Shimizu S, Hosomichi K, Kohara S, Watanabe S, Hanzawa K, Beck S, Kulski JK, Inoko H. 2004. Comparative genomic analysis of two avian - quail and chicken - major histocompatibility complex regions. J. Immunol., 172 (11): 6751-6763.

渡邊誠喜、永山文夫. 1979 . ウズラの血清 $\operatorname{IgG}$ 值に関 する研究. 日本家禽学会誌, 16: 59-64.

Wittzell H, von Schantz T, Zoorob R, Auffray C. 1994. Molecular characterization of three Mhc class II B haplotypes in the ring-necked pheasant. Immunogenetics, 39: 395-403.

Zoorob R, Bernot A, Renoir DM, Choukri F, Auffray C. 1993. Chicken major histocompatibility complex class II B genes: analysis of interallelic and interlocus sequence variance. Eur. J. Immunol., 23: 1139-1145. 